\title{
Competency of Professional Accountant in Malaysia as Attributes towards Compliance of AMLA 2001
}

Masetah Ahmad Tarmizi, Marina Ibrahim, Normah Omar, Suhaili Hasnan

To Link this Article: http://dx.doi.org/10.6007/IJARAFMS/v12-i1/11180 DOI:10.6007/IJARAFMS /v12-i1/11180

Received: 18 November 2021, Revised: 21 December 2021, Accepted: 29 December 2021

Published Online: 13 January 2022

In-Text Citation: (Tarmizi et al., 2022)

To Cite this Article: Tarmizi, M. A., Ibrahim, M., Omar, N., \& Hasnan, S. (2022). Competency of Professional Accountant in Malaysia as Attributes towards Compliance of AMLA 2001. International Journal of Academic Research in Business and Social Sciences, 12(1), 78-87.

Copyright: (c) 2022 The Author(s)

Published by Human Resource Management Academic Research Society (www.hrmars.com) This article is published under the Creative Commons Attribution (CC BY 4.0) license. Anyone may reproduce, distribute, translate and create derivative works of this article (for both commercial and non-commercial purposes), subject to full attribution to the original publication and authors. The full terms of this license may be seen at: http://creativecommons.org/licences/by/4.0/legalcode

Vol. 12, No. 1, 2022, Pg. 78 - 87

Full Terms \& Conditions of access and use can be found at http://hrmars.com/index.php/pages/detail/publication-ethics 


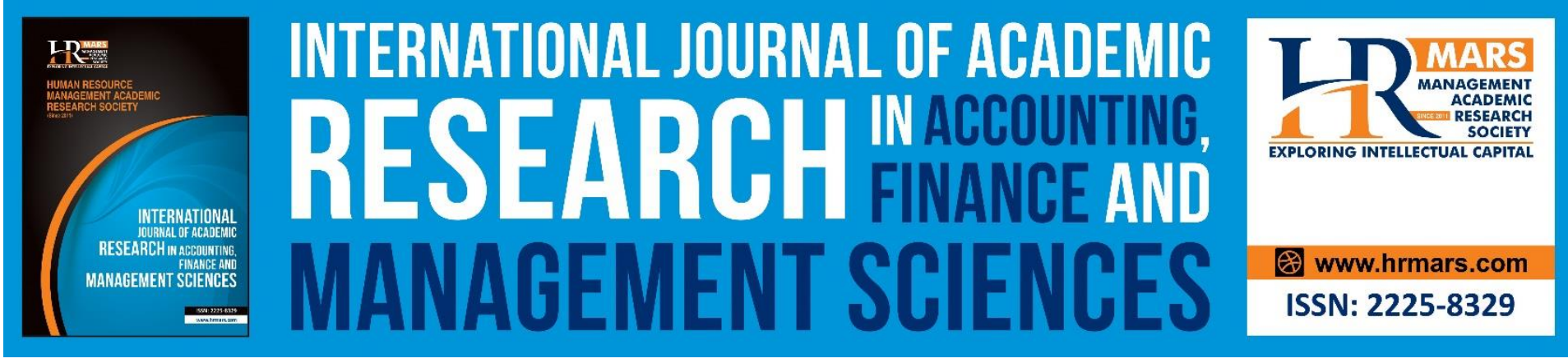

\title{
Competency of Professional Accountant in Malaysia as Attributes towards Compliance of AMLA 2001
}

\author{
Masetah Ahmad Tarmizia , Marina Ibrahimª, Normah Omar ${ }^{\mathrm{b}}$, \\ Suhaili Hasnan ${ }^{\mathrm{b}}$ \\ aFaculty of Accountancy, Universiti Teknologi MARA, Perak Branch, Tapah Campus, \\ 35400,Tapah Road, Perak, Malaysia, ' $F$ Faculty of Accountancy, Universiti Teknologi MARA, \\ Shah Alam, 40450, Selangor, Malaysia.
}

\begin{abstract}
Money laundering offences have becoming important issues worldwide. Within the accounting fraternity, discussions have involved an important issue related to the low level of compliance by professional accountants towards the anti-money laundering regime in Malaysia. In the context of this study, anti-money laundering regime refers to both the legislative requirements of the Anti-Money Laundering, Anti-Terrorism Financing and Proceeds of Unlawful Activities Act 2001 (AMLA 2001) and the international standards requirements of the Financial Action Task Force (FATF). Since the introduction of AMLA 2001, professional accountants (includes auditors, tax consultants and practicing accountants) have been named as a reporting institution. As a reporting institution, professional accountants are required to implement compliance programs and to submit related suspicious transaction reports. Three compliance programs named by the anti-money laundering regime are namely "Know your customers or KYC", "Clients due Diligent CDD" and "Record keeping". This study was undertaken to examine the importance of competency and training among professional accountant towards money laundering compliance. This study used Protection Motivation Theory to explain on the importance of that attributes. A questionnaire survey was developed and sent to professional accountants. Findings from this study have identified that "competency \& training" found to be significantly related to the level of compliance towards anti-money laundering regime.
\end{abstract}

Keywords: Money Laundering, Know Your Customer, Client Due Diligent, Compliance, Suspicious Transaction Reporting, Record Keeping, Competency, Training.

\section{Introduction}

Money laundering phenomena it's not new anymore to be introduced. The cases has widely known by many people and Malaysia have seen an increase of money laundering activities from year to year. In Malaysia, AMLA was introduced in 2001 with the objective to mitigate money laundering offences. Initially, AMLA 2001 was enforced to all financial institution however in 2004 it was imposed to designated non-financial businesses and 
MANAGEMENT SCIENCES

Vol. 12, No. 1, 2022, E-ISSN: 2225-8329 @ 2022 HRMARS

profession (DNFBP) which includes auditor, accountant, lawyer, notaries, real estate agents, trust, dealer of precious metal and stone and casinos. This group are responsible to comply with AMLA 2001. Due to the serious implications of this offences there are provisions in AMLA 2001 enabling to freeze, seize, and forfeit the illegal proceeds of crime as a stringent measure to mitigate money laundering activities. BNM stated that there are more than a hundred money laundering cases involving companies and individuals that are still waiting for trials (BNM website, 21 May 2019). Managing money laundering issues is challenging and difficult, as the money launderers had craftily analyses every aspect of the related laws to identify advantages on any loopholes. Currently, there are cases that have taken more than two years in collecting evidence, yet the prosecution is still ongoing due to the difficulty of determining the primal wrongdoings (Zakiah \& Khalijah (2012).

The advancement of the digital financial technology had further allow money launderers to become more creative whilst the legislation or regulation to mitigate such offences is still lagging or too slow to being operationalized. To further complicate matters, money launderers have started using the expertise of lawyers, accountants, auditors, company secretaries, and money changers in their criminal activities to facilitate on concealing their activities (Cabana (2007) and Ruiz (2004). Globally, this group of professionals mention above are named as Designated Non-Financial Business or Profession (DNFBP). DNFBP is a reporting institution listed in Paragraph 3.3 (a) to (k) of the AMLA 2001. On 2004, DNFBP also becoming one of the reporting institution and needs to comply with AMLA 2001. Professional accountants during the audit task should be able to detect any money laundering activities and being able to report to the BNM. It is understood that professional accountant should carried out all AMLA procedures known as CDD, KYC and record keeping

Currently, money launderers choose professionals like accountants and lawyers because the oldest modus operandi were through financial system, for example the banking institution, may not be easy for them. Banking institution had performed a number of efforts to mitigate money laundering. Most of the banks may easily identify those suspicious activities through their system and their well-trained employees. Professional accountants or lawyers are always chosen by the money launderers to act as a nominated person. They are appointed to perform certain duties or designated to perform certain acts or functions. In the money laundering context, they are aware of the risk, received instruction, performing task, and trustworthy (Nikoloska \& Simonovski, 2012). Accountants and lawyers may not realize that they have aided the money launderers to set up new company, purchase assets, and invest in securities and others.

This study will identified whether competency is determinant for the professional accountant to comply with AMLA 2001 rules and regulation.

\section{Literature Reviews and Research Theoretical Money laundering regime and development in Malaysia}

From the legislative perspective, the Malaysian Anti-Money Laundering Act 2001 defines money laundering as an " act that engages, directly or indirectly, in a transaction that involves proceeds of any unlawful activity, acquires, receives, possesses, disguises, transfers, converts, exchanges, carries, disposes, uses, removes from or brings into Malaysia proceeds of any unlawful activity; or conceals, disguises or impedes the establishment of the true nature, origin, location, movement, disposition, title of, rights with respect to, or ownership of, proceeds of any unlawful activity" (AMLA 2001, Part II, Section 4). Money laundering activities usually carried out through "structuring", "smurfing" or "blending". Splitting large 
MANAGEMENT SCIENCES

Vol. 12, No. 1, 2022, E-ISSN: 2225-8329 @ 2022 HRMARS

amount of financial transactions into smaller amounts is intended to avoid detection of money laundering. "Structuring" can be implemented through a series of "smurfing" which additionally makes it's difficult to identify money laundering. Structuring and smurfing can be used in placement which is the first stage of money laundering process and intends place illegal funds into financial system. The final stage known as integration, involves the integration of funds into the legitimate economy. This is realized through the purchase of assets such as real estate or luxury goods or by "blending" which means providing illegal funds to legal business by mixing such funds with legal income (Dobrowolski, 2019).

Being the gatekeepers of the AMLA regime, reporting institutions are encourage to systematically strengthened their procedures and enhance their roles in mitigating money laundering offences. The new FATF recommendations issued in 2012 for DNFBP, had no significant changes but the recommendations have been simplified to only two recommendations. Currently, DNFBP only need to comply with Recommendations 22 and 23. Recommendation 22 is specifically addressing on customer due diligence (CDD), which should be read together with Recommendations 10,11, 12, 15 and 17 of the FATF Recommendation. Recommendation 23 is specifically on the regulatory and supervision requirement (Normah et al., 2016b).

On the other hand, the compliance institution also need to comply with Know Your Customer (KYC), Client due diligent (CDD) and record keeping. All reporting institutions including DNFBP are required to take reasonable steps to gather the evidence about the identity of the new clients and to keep good update should there is any new information. The regulated firms also need to understand the client's nature of business. The maintenance of good KYC will help the firms to effectively manage the money laundering risk by reducing the likelihood that they will take a money launderer as their new customer or client and increasing the likelihood that they will detect the use of products and services for money laundering activities (Harvey, 2004). KYC rules start with the collection of client identification document, verification of document, to keep detailed and up-to-date records of their business relationship for a specified time, report of any suspicious transaction to the competent authority (FIED) and finally to respond to any enquiries from the FIED regarding the suspicious transactions. All reporting institutions of financial background or not will become a "traffic warden" that is required to provide information on the flow of the financial traffic, or in other words, they are responsible to detect any unusual or uncommon activities of their clients to the competent authority (Amicelle, 2011).

CDD involves conducting background investigations in order to ensure potential clients are not terrorist financiers, sanctioned persons, and members of organized crime groups (FATF, 2010). The vital element in conducting CDD is that the accountants must identify the background of the prospective clients and verify the identity of that client by cross referring them to reliable and independent documents. In short, from the literal explanation, CDD includes two definitions at least, which are due obligation and duty, and making persevering efforts to voluntarily obtain enough information ( $\mathrm{Ai}, 2009)$. CDD procedure is not only performed at the acceptance of the client, but also during the lifespan of the relationship with the client, as for accountants, the CDD procedure will be until the end of the contract of providing accounting or auditing services. Shehu (2010) stresses that CDD procedure must be written, documented, and clear; and adopt a risk based approach, so that the procedures are different from one client to another client based on their risk profile. The risk profile is determined by looking at the services of product offered, geographical location, complexity of business activity, and background of the client or beneficial owner. 
MANAGEMENT SCIENCES

Vol. 12 , No. 1, 2022, E-ISSN: 2225-8329 (C) 2022 HRMARS

Records of the customers and their transactions should be kept for a minimum of five years. This is necessary to provide a paper trail to the authorities in such case they need be to take legal action against the customer for any criminal activity (Sharma, 2005). In addition, the records kept must enable the reporting institutions to establish the history, circumstances, and reconstruction of each transaction. The records shall include at least the identity of the customer, the identity of the beneficiary, the identity of the person conducting the transaction, where applicable, the type of transaction (e.g. deposit or withdrawal), the form of transaction (e.g. by cash or by cheque), the instruction, origin, and destination of fund transfers, and the amount and type of currency (Dhillon, 2013). Shehu (2010, as cited in Kemal, 2014) adds location, method, and frequency of the transaction, as well as the source of the fund as part of the record are also needed. During an investigation, the ability to trace historical transaction is tremendously important (Sathye \& Islam, 2011). However, any document that is related to any money laundering case should be kept longer than the stipulated minimum requirement of six years, since it serves as an important evident (Haynes, 2008). Mugarura (2011) also claimed that training employees in record keeping and reporting suspicious transactions are the best tools to fight money laundering.

\section{Competency}

Competency emphasises an individual's capabilities and competence to cope with the task or make a choice (Bandura, 1977, 1991). Competency has been shown to have a significant impact on an individual's ability to accomplish task (Compeau \& Higgins, 1995). Competency is also known as expertise. Expertise can be divided into two. Firstly, it can be considered as knowledge that claims to be highly relevant for practical purposes. This is due to the nature of the type of knowledge that can be qualified as 'expertise'. Expertise is stored in professions and organisations, rather than in academic disciplines. Expertise can only be earned through working experience, which means, the longer you do the task, the more expert you will be. Secondly, expertise is a kind of knowledge that claims to be correct. This claim is difficult to be challenged by the users. Expertise is the knowledge produced and administered by specialists and can only be challenged by specialists. The expert competence is considered so advanced that it cannot be evaluated or controlled by people who do not have the same education and experience (Jacobsson, 2000). The inexpert person needs to trust the expert person (Hulsse \& Kerwer, 2007). A research performed by the Ifinedo (2011) on the information system security policy has suggested that competency would have a positive effect on the information system security compliance. This is consistent with the study done by Verkijiya (2018), which also found positive relationship between self-efficacy and smart phones security behaviour. The study also found that the detailed and comprehensive training provided had a significant gap in the attitudes between senior management and juniors. While senior management's attitudes were positive, junior staffs tend to perceive anti-money laundering activities as an extra burden in terms of banking operations due to the incomprehensive training given to them (Simwayi \& Guohua, 2011).

In the context of banking institution, competencies are known as crucial factors in detecting money laundering activities at the beginning, when being approached by the new customers, to assess the level of risk until writing in the suspicious transaction reports. A frontline officer has been named as first line of "defences" in screening the customers for money laundering risk potential. The damages become unbearable if money laundering risk has passed through the frontline officers due to the failure of frontline officers to screen the new customer's background. However, any money laundering risk detected after reviewing 
MANAGEMENT SCIENCES

Vol. 12, No. 1, 2022, E-ISSN: 2225-8329 @ 2022 HRMARS

the transaction of the new customer can be reported to BNM as suspicious transaction and the bank should not notify the customer regarding the report made to BNM (Isa, Sanusi et al., 2015). To continue promoting and maintaining expertise of human capital, this human capital should be provided with continuous education and training that are relevant, for example cutting edge technology, new financial instruments, regulation, policies, and the ability to trace and track illegal behaviour in the digital economy (Vaithilingam \& Nair, 2007). Competency of professional can be enhanced through providing sufficient training to the personnel.

In addition, providing training and ensuring that only the properly trained personnel handle any transactions, have become legal requirements in many countries (Sathye \& Islam, 2011). The importance of continuous training increases with the fast-paced advancement in money laundering techniques and the ever-evolving money laundering regulations. Continuous training programme will make the personnel to be updated with the sophisticated technology and new typologies of money laundering activities, thus making them to be motivated to detect money laundering transaction. Therefore, professional accountants should examine their anti-money laundering training strategies, goals, and objectives on an on-going basis and maintain effective anti-money laundering programmes that reflect the best practices.

The training given should clarifies about the AML legislation, rules, and procedures; the requirement of legislation bodies; the duties of competent authority as well as reporting institution; documentation; and most importantly to deal with typical customer and transaction of money laundering activities. All employees should be trained to be alert and watchful with regard to documents and answers by clients (Verhage, 2009). This is supported with the research done by Nagela (2019) on tax training which training may have increased the entrepreneur's knowledge about their financial obligations, regulations concerning deductions of business costs and their awareness with regard to penalties for incorrect deductions and increase compliance.

According to Zimeles (2004), training should include more real-life examples using a case study or role play. It is also found that, an effective training should focus more on the risks faced by the employees and needs of the reporting institutions, especially when it is given to the employees that work closely with the clients. This is because, if they are facing with a situation of suspicious activities, these employees are in the best position to detect the activities. Another research done by Dusabe (2016) found that knowledge and skill for individuals working in the AML sector, such as the FIU members, regulators, public prosecutors, the judiciary and the law enforcement bodies, are important to make them capable complying with the requirements.

\section{Research Theoretical}

This study will adopt Protection Motivation Theory (PMT), it has two components which are threat appraisal and coping appraisal. Threat appraisal includes three factors that explain how threats are perceived. These are basically rewards or benefits (any intrinsic or extrinsic motivation to increase or keep an unwanted behaviour), severity (the magnitude of the threat), and vulnerability (the extent to which the individual is perceived to be susceptible to the threat). Coping appraisal includes three factors that explain an individual's ability to cope with the threat. It is response efficacy (the belief in the perceived benefits of the coping action by removing the threat), response cost (cost incurred to the individual in implementing the protective behaviour), and self-efficacy (the degree that he or she believes it is possible 
MANAGEMENT SCIENCES

Vol. 12, No. 1, 2022, E-ISSN: 2225-8329 @ 2022 HRMARS

to implement the protective behaviour). This study, however will focused on the self-efficacy or renamed as "competency" to facilitate understanding of the readers.

\section{Research Methodology}

This research adopts a quantitative research method by employing survey research as the primary method. A questionnaire survey is used as a main instrument to collect data from professional accountants, who are also being members of the DNFBP group. The final questionnaires were sent to the selected sample either email or by post. Simple random sampling were used in this study.

Constructs have been operationalised using the Likert scales. The Likert type scale is a common approach used to measure a wide variety of latent constructs (Kent, 2001). In this research, the seven-point Likert scale, ranging from (7) strongly agree to (1) strongly disagree were used for anti-money laundering compliance (independent variables). For the dependent variable which refer to competency; (7) strongly implemented to (1) strongly unimplemented were applied for the implementation of the anti-money laundering compliance as stipulated by AMLA 2001 and FATF recommendations. Instead of using one single measurement for antimoney laundering compliance, the study examines all three requirements of AMLA 2001 which are CDD, KYC and record keeping.

There are eight (8) items in the training \& competency, namely (i) importance of AML training in detecting money laundering activities; (ii) extensive training to be provided by both BNM and MIA to improve money laundering detection capabilities among the professional accountants; (iii) training in money laundering will assist them in recognizing suspicious transaction; (iv) training materials to be used as a reference; (v) knowledge sharing gained from the training session with other members; (vi) adequate expertise gained from training to implement money laundering requirement as stipulated by AML regime (vii) training enhances ability to detect money laundering activities and (viii) are you capable to detect money laundering activities.

This study used SPSS to analysed all the data captured from the survey questionnaire. Some of the statistical procedures undertaken for the study would include techniques used to test data normality, data reliability, means scores, correlation between variables and linear regression analysis. Regression analysis is a set of statistical method to estimate the relationship between dependent variable and one or more independent variables. The regression equations are as follows:

MODEL : $A L L=a+a 1+s$

Where,

\section{Dependent Variable}

ALL: Magnitude of the variable referring to CDD, KYC and record keeping.

\section{Independent variable}

a1: Training \& Competency

\section{Result and Discussion}

This study focused to identify whether competency influence the compliance towards AMLA 2001 by professional accountants. Here, this item refers to a situation where professional accountants seek new knowledge through training in the area of anti-money 
MANAGEMENT SCIENCES

Vol. 12, No. 1, 2022, E-ISSN: 2225-8329 @ 2022 HRMARS

laundering regime (AMLA 2001 and FATF) in order to enhance their competency in detecting and mitigating money laundering offences. Based on descriptive analysis, interestingly, about ninety-five percent (95\%) of the respondents agreed on how five training-related items (i.e. knowledge sharing, training material, attendance of training, extensive training and the importance of training) contribute positively to the professional accountants. However, such training may not adequately enhance their competency and ability to either implement antimoney laundering regime effectively or to increase their ability to detect money laundering activities. Competency needs a lot of exposure and experience. The professional accountants need more time before they can be competent in detecting money laundering activities. Lack of competency among professional accountant would become one of the reason not to comply with AMLA 2001 and finally destroy the initiative of BNM to reduce money laundering cases.

Reliability test had performed for the competency \& training component which KMO at 0.769 . Cronbach's a value of 0.6 is the rule of thumb for describing internal consistency and it has been suggested that Cronbach's a value of 0.6 and greater indicate excellent congruence and composite reliability (Zinbarg et al., 2006). Hence the reliability test on competency \& training was accepted. The skewness and kurtosis of competency \& training which are 0.292 and 0.143 fell between 1.90 and -1.96 which means normality can be assumes at 0.05 significance level. In addition, there is no evidence of multicollinearity as the correlation between the variable fell below 0.9. Refer to Table 1 for the regression result.

Table 1: Result of regression between training and competency and compliance of AMLA (Know Your Customer, Client Due Diligent and Record Keeping)

\begin{tabular}{llll}
\hline Variable & Coefficients & T stat & P value \\
\hline Independent variable & & & \\
Competency and Training & 0.192 & 2.554 & 0.011 \\
R square & 0.454 & & \\
Adjusted r square & 0.413 & & \\
\hline
\end{tabular}

Based on Table 1, significant positive relationship is observed between money laundering compliance and training \& competency $(R 2=.454), p=.000)$. Standardised beta coefficient of 0.63579 of money laundering compliance shows that training \& competency make a strong and unique contribution in explaining money laundering compliance.

Competency is positively influence compliance among professional accountant in accordance to money laundering requirement. This study are consistent with the studies done by (Ifinedo, 2011; Verkijiya, 2018; Lwin et al., 2012). The results can be supported by the existing literature that the importance of continuous training increases within the fast-paced advancement in money laundering techniques and the ever evolving money laundering regulations. Continuous training programme will make professional accountants up to date with new AMLA 2001 and FATF requirement, latest and sophisticated technology (hardware and software) and new typologies of money laundering activities. In addition, Dusabe (2016) found that knowledge and skill for individuals working with the AML sector is crucial so that they are capable to comply with the requirements. Lacking knowledge on the basic of AML requirements as well as limited resources has negatively affected the smooth implementation of AML programmes (Subbotina, 2009).

Training and competency will become an important weapon in the implementation of anti-money laundering programme. Training provided by regulators as well as reporting 
MANAGEMENT SCIENCES

Vol. 12, No. 1, 2022, E-ISSN: 2225-8329 @ 2022 HRMARS

institutions is known to be a gateway for the AMLA implementation. Without proper knowledge and training, all programmes relating to AMLA cannot be attainable. MIA may encourage training on AMLA regime as part of important training that should be obtained by all professional accountants every year. This is to ensure that all professional accountants keep up to date with any changes within the laws. CPE hours can be introduced to make the training become compulsory.

Competency is important in the process of detection of any suspicious transactions and activities; however, the professional accountant needs to be aware of the nature of client's business and industry so that it will help to determine any suspicious transactions. BNM should encourage all reporting institution to always add their knowledge and expertise by attending training and seminars. Those training and seminars can be initiated by BNM, MIA, MICPA or any other institutions.

As conclusion, this study highlight on the compliance among professional accountant towards AMLA 2001 regime. It is discovered that training and competency becoming one of the determinant that encourage compliance among professional accountants. Extensive training will promote competency among professional accountants and this will lead to more compliance towards AMLA 2001 regime. As for recommendations, provision of training and workshop by the accounting bodies in Malaysia such as MIA, MICPA, ACCA and ICAEW are highly appreciated. The training should strengthening the understanding of professional accountant towards AMLA 2001 regulation and covers widely area such as real life example of money laundering transactions, the audit trail, the movement of money laundering from one region to another region, the used of software or any artificial intelligence for detection mechanism of money laundering transaction and many more. Hopefully, by then compliance industry (professional accountants) will achieve full compliance of AMLA 2001 in the future.

\section{References}

Ai. (2009), The international standards of customer due diligence and Chinese practice, Journal of Money Laundering Control ,Vol. 12 No. 4, pp. 406-416

Amicelle. (2011), Towards a 'new' political anatomy of financial surveillance, Special Issue on The Global Governance of Security and Finance, Security Dialogue, 42(2), pp 161-178. Anti-Money Laundering Act 2001

Cabana. (2007), Legal professionals and money laundering in Spain, Journal of Money Laundering Control, Vol. 10 No. 3, pp $318-336$.

Dhillon, G., Ahmad, R., Rahman, A., and Ng, Y. M. (2013), The viability of enforcement mechanisms under and anti-terrorism offences in Malaysia An overview, Journal of Money Laundering Control, Vol. 16 No. 2, pp. 171-192.

Dusabe, F. (2016),"Rwanda: Assessing the effectiveness of legal and policy responses to fight Money Laundering ", Journal of Money Laundering Control, Vol. 19 Iss 1 pp. 21 - 31

Haynes. (2008),"Money laundering: from failure to absurdity", Journal of Money Laundering Control, Vol. 11 Issues 4, pp. $303-319$.

Hulsse and Kerwer. (2007), Global Standards in Action: Insights from Anti-Money Laundering Regulation, Volume 14(5, pp. 625-642.

Ifinedo. (2012), Understanding information systems security policy compliance: An integration of the theory of planned behaviour, Journal of Computers \& Security, Volume 31, pp 83-95.

Jacobsson. (2000), A world of Standard, Oxford: Oxford University Press, pp. 188 
MANAGEMENT SCIENCES

Vol. 12, No. 1, 2022, E-ISSN: 2225-8329 @ 2022 HRMARS

Lwin, M. O., Li, B., Ang, R. P. (2012), Stop bugging me: an examination of adolescents' protection behavior against online harassment, protection behavior against online harassment. J Adolesc; 35: page 31-41.

Mugarura. (2014), Customer due diligent mandate and the propensity of its application as a global AML paradigm, Journal of Money Laundering Control, No 1, pp 76 - 95.

Mugurura. (2011), The institutional framework against money laundering and its underlying predicate crimes, Journal of Financial Regulation and Compliance, Volume 19 No. 2, pp. 174-194.

Nikoloska \& Simonovski. (2012), Role of banks as entity in the system for prevention of money laundering in the Macedonia, Journal of Social and Behavioral Sciences, Volume 44, pp. 453-459.

Normah, O., Razana, J., Sathye, M. (2016a), Malaysian DNFBPs' Perceptions on Awareness, Perceived Impact and Views on the AML/CFT Requirements

Normah, O., Johari, R. J., Azam, M. A. M., Hakim, N. O. (2016b) Mitigating Money Laundering: The Role of Designated Non-financial Businesses and Professions in Southeast Asian Countries. In: Djajadikerta H., Zhang Z. (eds) A New Paradigm for International Business. Springer Proceedings in Business and Economics. Springer, Singapore

Ruiz, M. (2004),"Lawyers and money laundering", Journal of Money Laundering Control, Vol. 7 Issues 3 p. 272-274 http://dx.doi.org/10.1108/13685200410809977

Sathye \& Islam. (2011), adopting a risk-based approach to AMLCTF compliance: the Australian case, Journal of Financial Crime, Vol. 18 No. 2, pp. 169-182.

Simwaye and Wang. (2011), The role of money laundering reporting officers in combating money laundering in Zambia, Journal of Investment Compliance, VOL. 12 NO. 3, pp. 4955.

Shehu. (2010), Promoting financial sector stability through an effective AML/CFT regime, Journal of Money Laundering Control, Vol. 13 No. 2, pp. 139-154.

Simwayi and Guohua. (2011), The role of commercial banks in money laundering, Journal of Money Laundering Control, Vol. 14 No. 4, pp $324-333$.

Subbotina, N. (2009), "Challenges that Russian banks face in implementing the anti-money laundering regulations", Journal of Money Laundering Control, Vol. 12 No. 1, pp. 19-32.

Tsai, H. S., Jiang, M., Alhabash, S., LaRose, R., Rifon, N. J., Cotton, S. R. (2016), Understanding online safety behaviors: a protection motivation theory perspective. Computer Security 2016; 59:138-50.

Vaithilingam, S., and Nair, M. (2007), "Factors affecting money laundering: lesson for developing countries", Journal of Money Laundering Control, Vol. 10 No. 3, pp. 352-366

Verhage. (2009), Supply and demand: anti-money laundering by the compliance industry, Journal of Money Laundering Control, Volume. 12 No. 4, pp. 371-391.

Zimiles. (2004),"KPMG Survey: Banks accept more costly money-laundering laws, expect heightened cooperation with regulators", Journal of Investment Compliance, Vol. 5 Issues 3 pp. $26-30$. 